\title{
Clinical spectrum and diagnostic pitfalls of neurologic syndromes with $\mathrm{Ri}$ antibodies
}

Claire Simard, MD,* Alberto Vogrig, MD,* Bastien Joubert, MD, Sergio Muñiz-Castrillo, MD, Géraldine Picard, MSc, Véronique Rogemond, PhD, François Ducray, MD, PhD, Giulia Berzero, MD, Dimitri Psimaras, MD, Jean-Christophe Antoine, MD, PhD, Virginie Desestret, MD, PhD, and Jérôme Honnorat, MD, PhD

Neurol Neuroimmunol Neuroinflamm 2020;7:e699. doi:10.1212/NXI.0000000000000699

\section{Abstract}

\section{Objective}

To describe the main syndrome and clinical course in a large cohort of patients with anti-Ri-associated paraneoplastic neurologic syndrome (Ri-PNS).

\section{Methods}

Twenty-year retrospective nationwide study and systematic review of the literature.

\section{Results}

Thirty-six patients with complete clinical information were identified (median age 66 years, range: 47-87 years). In this French cohort, the majority were women (78\%). At onset, 4 main patterns were observed: cerebellar syndrome (39\%), isolated tremor (24\%), oculomotor disturbances (17\%), and other symptoms (19\%). Course was multistep for $78 \%$ of cases. At the time the disease reached the plateau phase (median 12 weeks, range: 1-64 weeks; $28 \%>3$ months), 24 (67\%) showed an overt cerebellar syndrome, which was isolated in 3 patients, and was most frequently (21/24 cases) part of a multisystem neurologic disease. Patients manifested a variety of movement disorders, including myoclonus (33\%), dystonia (17\%), either cervical or oromandibular, and parkinsonism (17\%). Most patients had cancer $(92 \%)$, mainly breast cancer $(n=22)$. Misdiagnoses concerned $22 \%$ of patients $(\mathrm{n}=8)$ and included atypical parkinsonism $(\mathrm{n}=2)$, MS $(\mathrm{n}=2)$, Bickerstaff encephalitis $(\mathrm{n}=1)$, hyperekplexia $(\mathrm{n}=1)$, vestibular neuritis $(\mathrm{n}=1)$, and functional neurologic disorder $(\mathrm{n}=1)$. Survival at 12 months was $73 \%$ (95\% CI [0.54-0.85]), at 24 months $62 \%$ (95\% CI [0.41-0.78]), and at 36 months $47 \%$ (95\% CI [0.25-0.65]). There was no major clinical difference between cases retrieved from the systematic review of the literature $(n=55)$ and the French cohort.

\section{Conclusions}

Ri-PNS is a multisystem neurologic syndrome with prominent cerebellum/brainstem involvement. Opsoclonus-myoclonus is less common than expected, and the disorder can mimic neurodegenerative diseases.

\author{
Correspondence \\ Dr. Honnorat \\ jerome.honnorat@chu-lyon.fr
}

MORE ONLINE

Q Videos

\footnotetext{
*These authors contributed equally to this work.

From the Centre de Référence National pour les Syndromes Neurologiques Paranéoplasique (C.S., A.V., B.J., S.M.-C., G.P., V.R., F.D., J.-C.A., V.D., J.H.), Hôpital Neurologique, Hospices Civils de Lyon; SynatAc Team (C.S., A.V., B.J., S.M.-C., G.P., V.R., F.D., V.D., J.H.), NeuroMyoGene Institute, INSERM U1217/CNRS UMR5310; Université Claude Bernard Lyon 1 (C.S., A.V., B.J., S.M.-C., G.P., V.R., F.D., V.D., J.H.), Université de Lyon; AP-HP (G.B., D.P.), Groupe Hospitalier Pitié-Salpêtrière, Service de Neurologie 2-Mazarin et Université Pierre et Marie Curie-Paris 6, Centre de Recherche de l'Institut du Cerveau et de la Moelle Epinière (CRICM), UMRS 975; Inserm U 975 (G.B., D.P.), CNRS, UMR 7225; Centre de Compétence des Syndromes Neurologiques Paranéoplasiques et Encéphalites Autoimmunes (G.B., D.P.), Groupe Hospitalier Pitié-Salpêtrière, Paris; and Service de Neurologie (J.-C.A.), CHU de Saint-Etienne, SaintEtienne, France.
}

Go to Neurology.org/NN for full disclosures. Funding information is provided at the end of the article.

The Article Processing Charge was funded by INSERM ADR05; Institut Neuromyogène INSERM U1217 CNRS 5310.

Data access, responsibility, and analysis: The corresponding author had full access to all the data in the study and takes responsibility for the integrity of the data and the accuracy of the data analysis.

This is an open access article distributed under the terms of the Creative Commons Attribution-NonCommercial-NoDerivatives License 4.0 (CC BY-NC-ND), which permits downloading and sharing the work provided it is properly cited. The work cannot be changed in any way or used commercially without permission from the journal. 


\section{Glossary}

BBE = Bickerstaff brainstem encephalitis; HER2 = human epidermal growth factor receptor 2; ICU = intensive care unit; IVIG = IV immunoglobulin; $\mathbf{m R S}=$ modified Rankin Scale; NOVA $=$ neuro-oncologic ventral antigen; OMS $=$ opsoclonusmyoclonus syndrome; PSP = progressive supranuclear palsy; Ri-PNS = Ri-associated paraneoplastic neurologic syndrome; SIADH = syndrome of inappropriate antidiuretic hormone secretion; SPS = stiff-person syndrome.

Opsoclonus-myoclonus syndrome (OMS) is considered to be the stereotypical manifestation of a paraneoplastic neurologic syndrome associated with autoantibodies targeting the intracellular $\mathrm{Ri}$ antigen (Ri-PNS) in patients with breast cancer. ${ }^{1-8}$ Following the original descriptions of Ri-PNS, subsequent reports described diverse neurologic presentations (including patients with peripheral nervous system disorders $)^{9}$ and different oncological associations (e.g., lung cancer). ${ }^{10}$ Disease course, differential diagnosis spectrum, and long-term outcome remain to be clarified.

To improve the recognition of this disease, we report and analyze herein the clinical features of previously unpublished patients with Ri-PNS resulting from a 20-year, retrospective, nationwide study at the "Centre de référence des syndromes neurologiques paranéoplasiques et encéphalites autoimmunes" (Lyon, France) and compare this French cohort with cases identified from a systematic review of the literature.

\section{Methods}

\section{Patients}

We retrospectively included all the patients identified between January 1, 1999, and December 31, 2018, whose serum and/or CSF were found to be positive for Ri antibodies. Positivity was defined by 2 complementary detection methods: staining of nucleus and cytoplasm of neurons by indirect immunofluorescence on rat brain sections and a positive confirmation test using a cell-based assay (immunodot, or Western blotting with recombinant protein), as recommended. ${ }^{11}$ Clinical data were obtained by reviewing the case records of first admission and serial follow-up examinations. Patients with insufficient information (i.e., lacking information on clinical presentation, cancer association, and paraclinical investigations) were excluded from the analysis. Outcomes were assessed using the modified Rankin Scale (mRS); this scale ranges from 0 (no symptoms) to 6 (death). All patients provided written informed consent for the storage and use of their serum, CSF, and clinical information for research purposes. The study was approved by the Institutional Review Board of the University Claude Bernard Lyon 1 and Hospices Civils de Lyon.

\section{Search strategy}

A systematic review of the literature was conducted following the Preferred Reporting Items for Systematic Reviews and Meta-Analyses (PRISMA) reporting guidelines. ${ }^{12}$ We searched PubMed for records published in English or French language between January 1, 1988, and January 1, 2018, using the following search terms: (1) the text words "Anti-Ri"; (2) the MeSH term "paraneoplastic syndromes" AND the text words "ANNA-2" OR "NOVA 1" OR "NOVA2." In addition, the reference lists of all selected articles were perused to identify any articles missed. The following data items were extracted from the studies: demographic data, neurologic symptoms, and their mode of onset (defined as acute if developing in $<1$ week; subacute: between 1 week and 3 months; progressive: $>3$ months), paraclinical data, and type of cancer.

\section{Comparison between the literature and the French cohort of patients}

We questioned whether the clinico-demographic features of the French cases were different from those of the patients reported in the literature. To perform a comparison between the 2 groups, we included only confirmed cases who did not present with coexisting autoantibodies to have a homogeneous series of patients with an identical biomarker.

\section{Statistical methods}

Data are presented as frequencies and percentages for categorical variables and as median and range for continuous variables. Categorical data were analyzed using the Fisher exact test $(2$ tailed $)$ and numerical data using the MannWhitney $U$ test. Survival rates were based on Kaplan-Meier estimation with $95 \%$ CI. Statistical analyses were performed using the SPSS Statistics software (IBM Corp., Armonk, NY). $p$ Values $<0.05$ were considered significant.

\section{Data availability}

Data reported in this article are available within the article or its supplementary materials. More information regarding the data is available from the corresponding author on reasonable request.

\section{Results}

\section{Clinical features}

A total of 40 patients with Ri-PNS were identified. Four patients were excluded due to insufficient clinical information, leaving a series of 36 previously unpublished cases for analysis (table e-1, links.lww.com/NXI/A225). The median age at disease onset was 66 years (range: $47-87$ years), and most patients were women (78\%). As the majority (78\%) of cases had a multistep disease course, we separated the neurologic features present at onset (figure 1A) from those that constituted the established syndrome (figure 1B). 
A. Symptom at onset

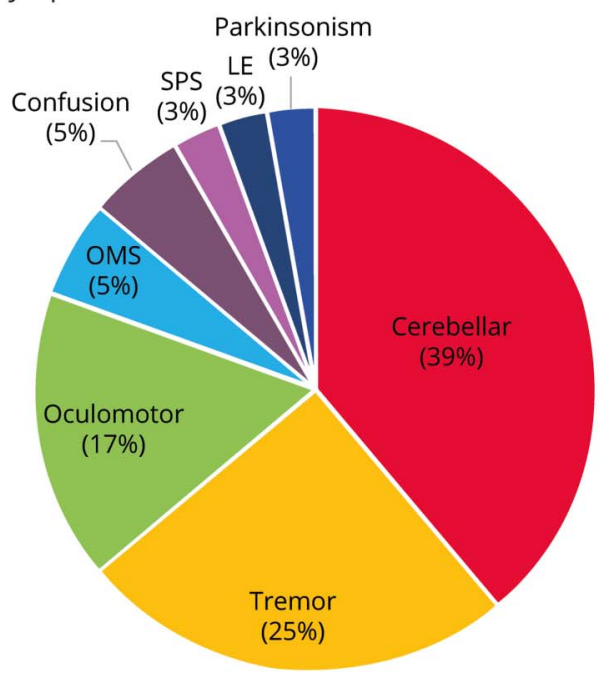

C

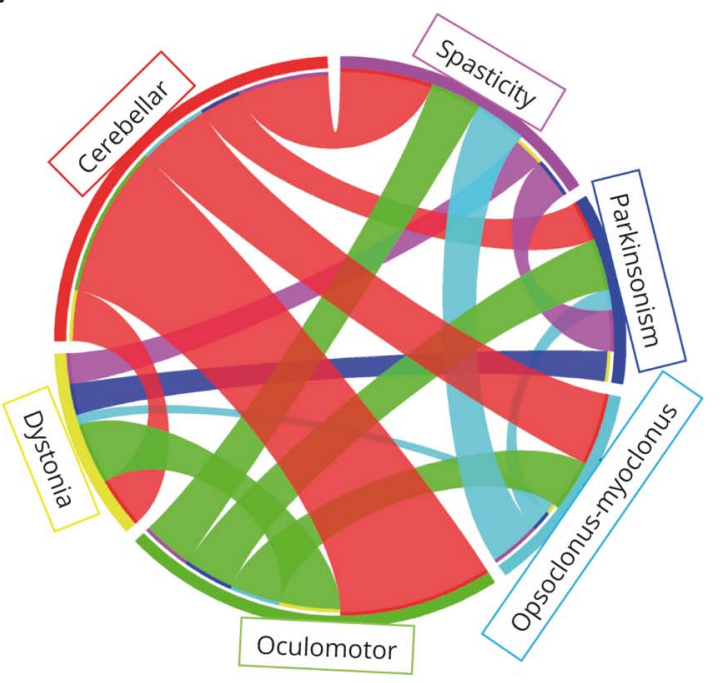

B. Established syndrome

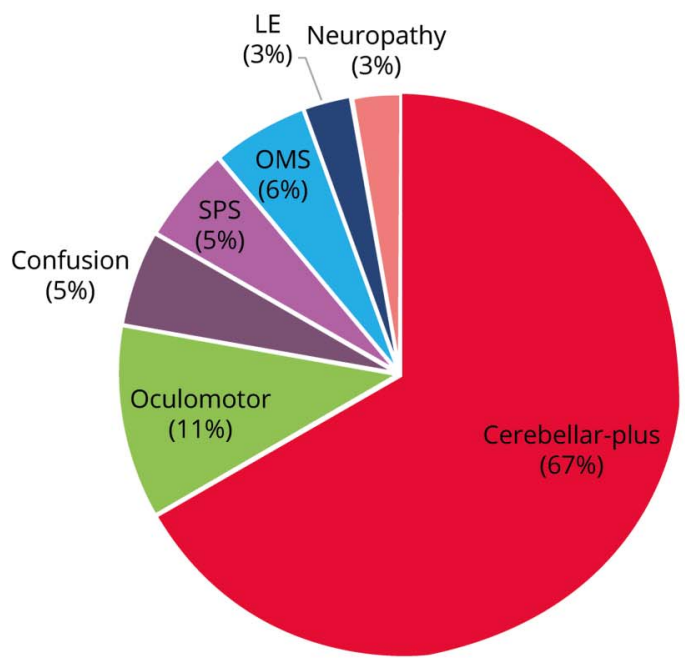

D

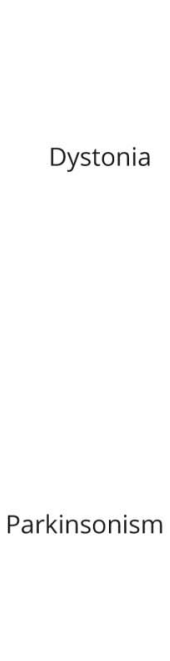

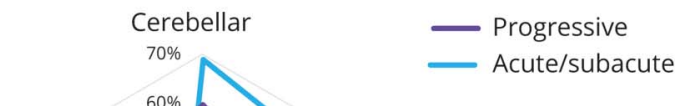

- Progressive
Acute/subacute

Oculomotor

Spasticity

Clinical features at onset (A) and in the established syndrome (B) in the French Cohort of patients with Ri-PNS $(n=36)$. (C) Schematic representation of the complex association of neurologic signs in Ri-Ab-associated syndrome. The interactions between clinical phenomenologies in Ri-Ab-associated syndrome in a Circos plot ${ }^{31}$ with co-occurrence of cerebellar syndrome, oculomotor disturbances, movement disorders, and opsoclonus-myoclonus. (D) Differences in the clinical spectrum in progressive (violet) and acute/ subacute (light blue) forms. LE = limbic encephalitis; Ri-Ab = Ri-antibody; Ri-PNS = Ri-associated paraneoplastic neurologic syndrome; SPS = stiff-person syndrome.

At disease onset, 4 main patterns were observed: cerebellar syndrome $(n=14,39 \%)$, isolated tremor $(n=9,25 \%)$, oculomotor disturbances $(n=6,17 \%)$, and other symptoms $(n=7$, $19 \%)$. The cerebellar ataxia presentation (14 patients) consisted of gait ataxia associated with action tremor. All the 9 patients presenting with isolated tremor had action tremor involving the upper limbs; in 7/9 cases, it progressed subsequently into an overt cerebellar syndrome. The 6 patients with an oculomotor presentation initially complained of diplopia. Four of them had objective oculomotor deficits on neurologic examination (complete ophthalmoplegia in 2 cases, internuclear ophthalmoplegia in 1 case, and third cranial nerve palsy in 1 case). In the 7 remaining patients, a variety of other CNS signs were observed (OMS, $\mathrm{n}=$ 2; confusion, $\mathrm{n}=2$; stiff-person syndrome [SPS], $\mathrm{n}=1$; limbic encephalitis, $\mathrm{n}=1$; parkinsonism, $\mathrm{n}=1$ ).

At the time the disease reached the plateau phase (median 12 weeks, range: $1-64$ weeks; $28 \% \geq 3$ months), 24 patients (67\%) had symptoms and signs of a cerebellar syndrome (figure $1 \mathrm{~B}$ and video 1$)$. The cerebellar dysfunction rarely remained isolated $(\mathrm{n}=$ 3; $8 \%$ ) and was most commonly associated with other symptoms/signs (figure 1C): oculomotor disturbances $(\mathrm{n}=15$; $42 \%)$, opsoclonus with or without myoclonus ( $n=10 ; 28 \%$ ), spasticity $(n=9 ; 25 \%)$, dystonia $(n=5 ; 14 \%)$, and parkinsonism 
$(n=4 ; 11 \%)$. Among all cases, the cerebellar syndrome was the most common component of the full-blown presentation. Seventeen patients with initial cerebellar dysfunction developed signs of brainstem involvement as a secondary step. When the clinical findings did not include a cerebellar syndrome (12 cases; $33 \%$ of the total population), the neurologic disorder was more heterogeneous, consisting of oculomotor disturbances $(\mathrm{n}=2)$, oculomotor disturbances and parkinsonism $(n=2)$, recurrent episodes of confusion $(\mathrm{n}=2)$, OMS associated with spastic paraparesis ( $\mathrm{n}$ $=2)$, SPS $(n=2)$, limbic encephalitis $(n=1)$, and peripheral neuropathy $(\mathrm{n}=1)$. The patient manifesting limbic encephalitis was a 50-year-old man who presented with psychomotor slowing, behavioral disturbances, and short-term memory loss (minimental state examination 17/30).

Other than cerebellar ataxia, the patients manifested a variety of movement disorders, including myoclonus $(\mathrm{n}=12,33 \%)$, dystonia $(n=6,17 \%$; either cervical, $n=4$, or jaw-opening [oromandibular] dystonia, $n=2)$, and parkinsonism $(n=6,17 \%)$. All patients with parkinsonism showed bradykinesia and rigidity, whereas only 2 of them also presented with tremor. Parkinsonian features involved asymmetrically the upper limbs and appeared later over the course of the disease in $4 / 6$ patients. In the other 2 patients, parkinsonism was an early manifestation and involved the lower limbs. Supranuclear gaze palsy or ophthalmoplegia associated with parkinsonism was observed in $5 / 6$ patients. Treatment with levodopa was introduced in 2 patients without clinical improvement. All those with parkinsonism were female patients with breast cancer (video 2). Among all patients, 13 (36\%) developed regional or diffuse pyramidal hypertonia (spasticity), 2 of them in the context of SPS. Sex-related clinical specificities were observed as spasticity and dystonia were present only in female patients, and only male patients presented with transient, recurrent episodes of confusion (figure 2A).

Atypical symptoms and signs were also detected in a minority of patients $(n=5,14 \%)$. Three ( $8 \%)$ developed hyponatremia due to a concomitant syndrome of inappropriate antidiuretic hormone secretion (SIADH). Two others (5\%) had severe dysautonomia (including heart rate instability and recurrent cardiorespiratory arrest) and central hypoventilation (Ondine syndrome).

Misdiagnoses concerned 22\% of patients $(n=8): 2$ of the patients from the French cohort were initially diagnosed with MS, 2 with atypical parkinsonism, 1 with Bickerstaff encephalitis, 1 was extensively studied for a genetic form of hyperekplexia, 1 with vestibular neuritis, and 1 was considered to have a functional neurologic disorder.

\section{Oncologic associations}

Thirty-three patients (92\%) developed a cancer within 5 years, most commonly breast cancer $(n=22)$. None of the 14 patients with breast cancer for whom human epidermal growth factor receptor 2 (HER2) status was available were HER2 positive. The type of cancer was significantly associated with the sex of the patient $(p<0.001)$ : as expected, breast cancer was more frequent in female patients $(p<0.001)$, whereas atypical cancer types (other than breast and lung cancer) were more frequent in men $(p<0.001)$, including neuroendocrine tumors and mediastinal seminoma (figure $2 \mathrm{~B}$ ).

Among patients with cancer $(\mathrm{n}=33)$, the neurologic syndrome preceded the discovery of cancer in $24(73 \%)$ patients, diagnosis of cancer and PNS were concomitant ( $<1$ month) in 5 $(15 \%)$ patients, and the neurologic manifestations followed diagnosis of cancer in 4 patients (12\%). The 3 patients without cancer were women (age range: 52-83 years), with similar clinical findings as those with tumors (cerebellar syndrome and oculomotor disturbances in 2; SPS in 1).

\section{Paraclinical data}

CSF analysis found pleocytosis in $36 \%$ of patients, increased protein content in $68 \%$, and detection of oligoclonal bands in $80 \%$, the latter being the most common CSF abnormality. Only a single CSF analysis was normal if all these 3 parameters were analyzed concomitantly. Brain MRI results were available for 33 patients (92\%) and was abnormal in 6 (18\%); 5 cases had T2 signal changes in the brainstem (in 1 case, the brainstem lesion coexisted with mesial temporal lobe signal abnormality, with contrast enhancement), and 1 demonstrated an isolated supratentorial lesion (left pallidum hyperintensity). The location and type of neuroradiologic abnormalities are shown in figure 3. Three patients $(8 \%)$ had coexisting neural antibodies against glutamic acid decarboxylase, $\mathrm{Hu}$, and glutamic acid decarboxylase/Sox-1, respectively (table e-1, links.lww. com/NXI/A225).

\section{Outcome and immunotherapy treatment}

All patients with cancer $(n=33)$ received oncological treatment. In addition, 21 patients (58\%) received immunotherapy: $6(17 \%)$ received only corticosteroid bolus; 5 (14\%) IV immunoglobulin (IVIG); 7 (19\%) a combination of corticosteroids and IVIG; and 3 (8\%) received cyclophosphamide as second-line immunotherapy. The median duration of followup was 13 months (range: 1-132 months). Outcome measured by the $\mathrm{mRS}$ was available for 22 patients. The median mRS score at disease onset was 3 (moderate disability). At 12 months, the median mRS score was 4 (moderately severe disability; the patient is unable to walk unassisted). Patient 21 showed spectacular improvement in neurologic symptoms (oculomotor disturbance and cerebellar syndrome) following breast cancer treatment with farmorubicin and cyclophosphamide. Using the Kaplan-Meier method, the overall survival at 12 months was estimated to be $73 \%$ (95\% CI [0.54-0.85]), $62 \%$ at 24 months (95\% CI [0.41-0.78]), and $47 \%$ at 36 months $(95 \%$ CI $[0.25-0.65])$. There was no significant difference in overall survival according to use of immunotherapy $(\log$-rank $p=0.615)$ or presence of cancer $(\log -\operatorname{rank} p=0.893)$.

\section{Literature review}

We screened 47 studies (41 isolated observations and 6 case series, detailed in tables e-2 and e-3, links.lww.com/NXI/A225) 


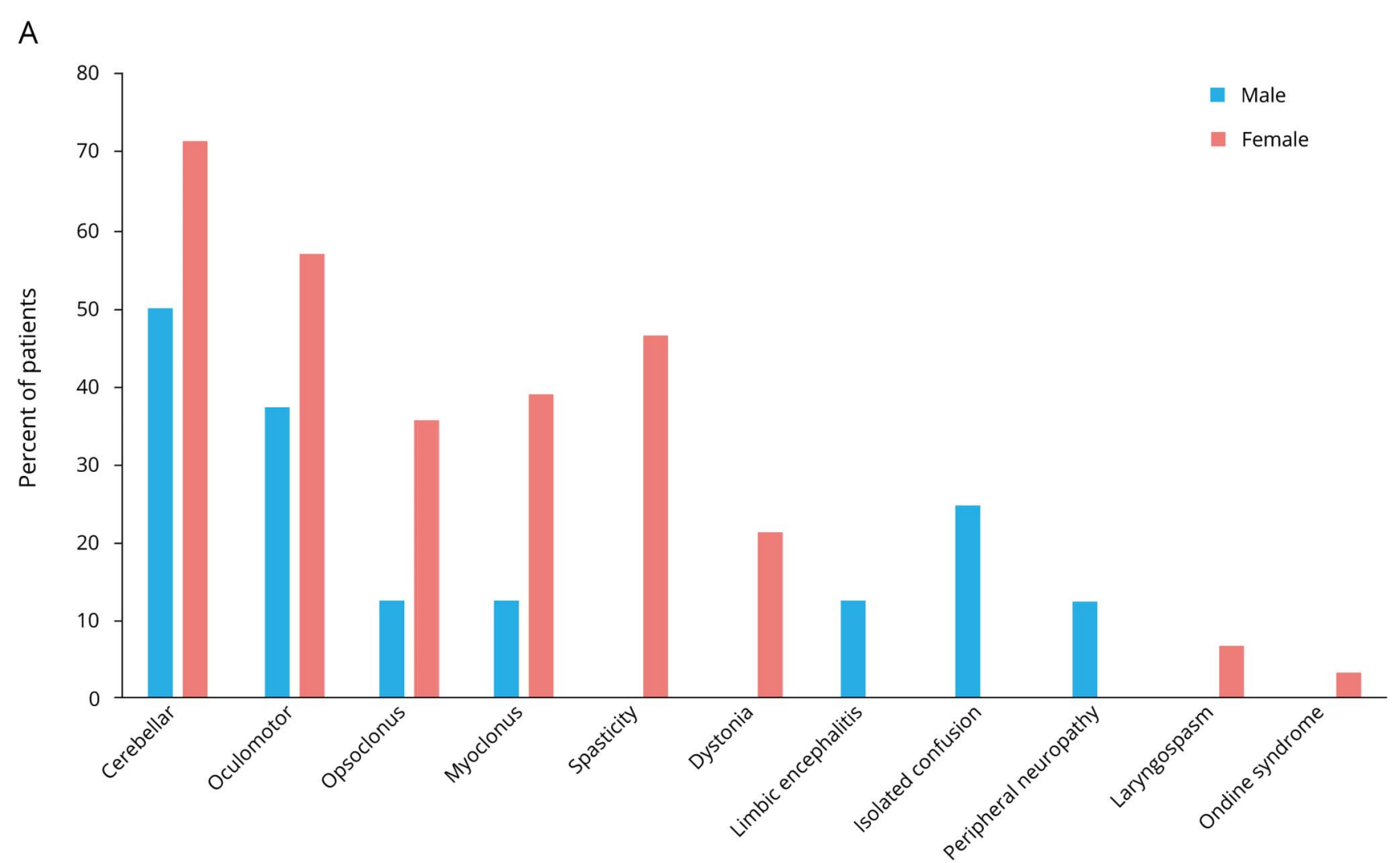

B

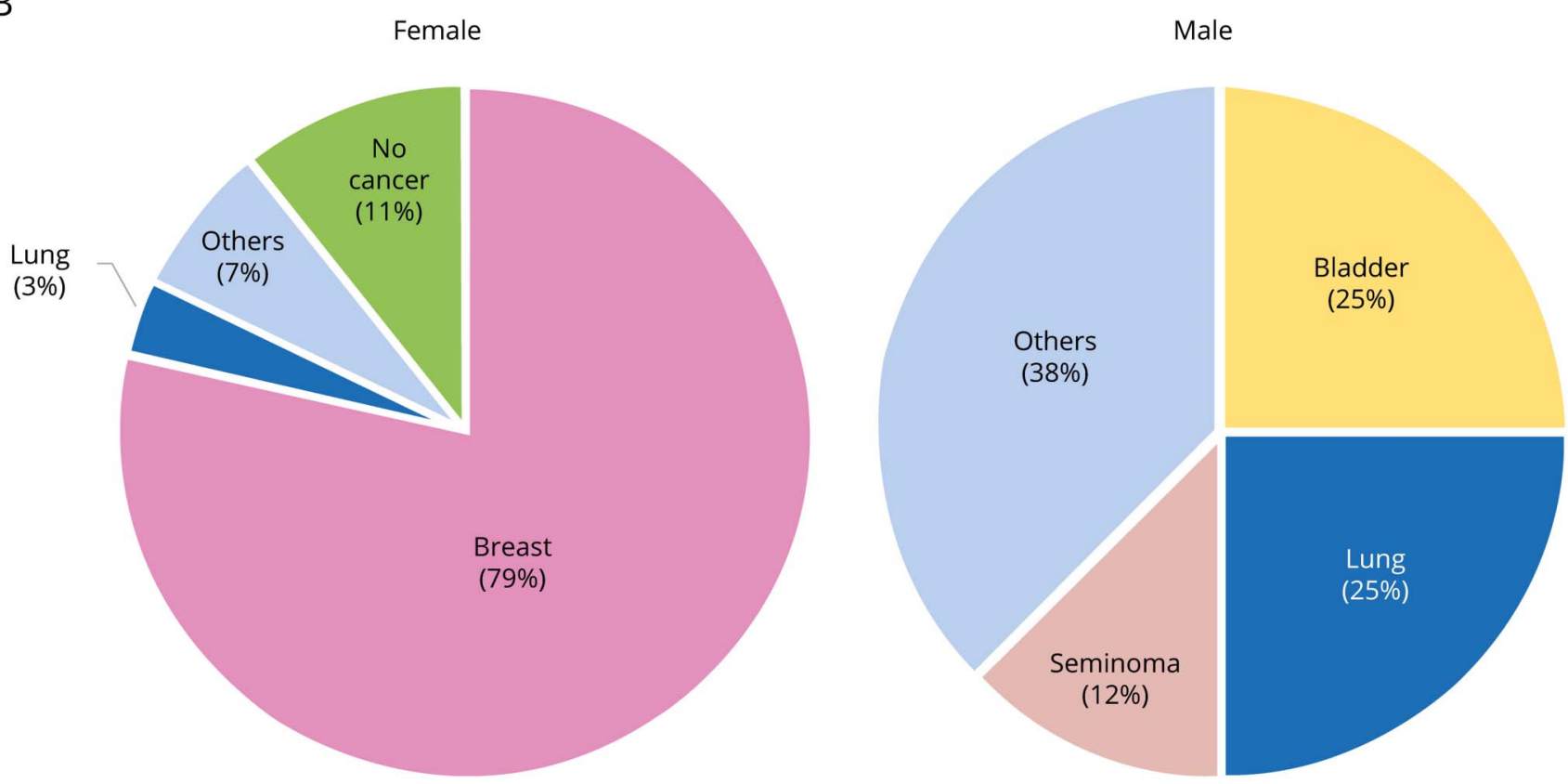

Clinical (A) and oncological (B) sex-related specificities. Ri-PNS = Ri-associated paraneoplastic neurologic syndrome.

of the 171 records identified through the PubMed search (figure e-1, links.lww.com/NXI/A225). After removing studies that did not fulfill with the inclusion criteria, 27 studies (describing 55 cases) were included for final analysis.

\section{Comparison between the French cohort and the literature review}

Three patients were excluded from the French cohort due to the presence of coexisting antibodies, leaving 33 patients for 

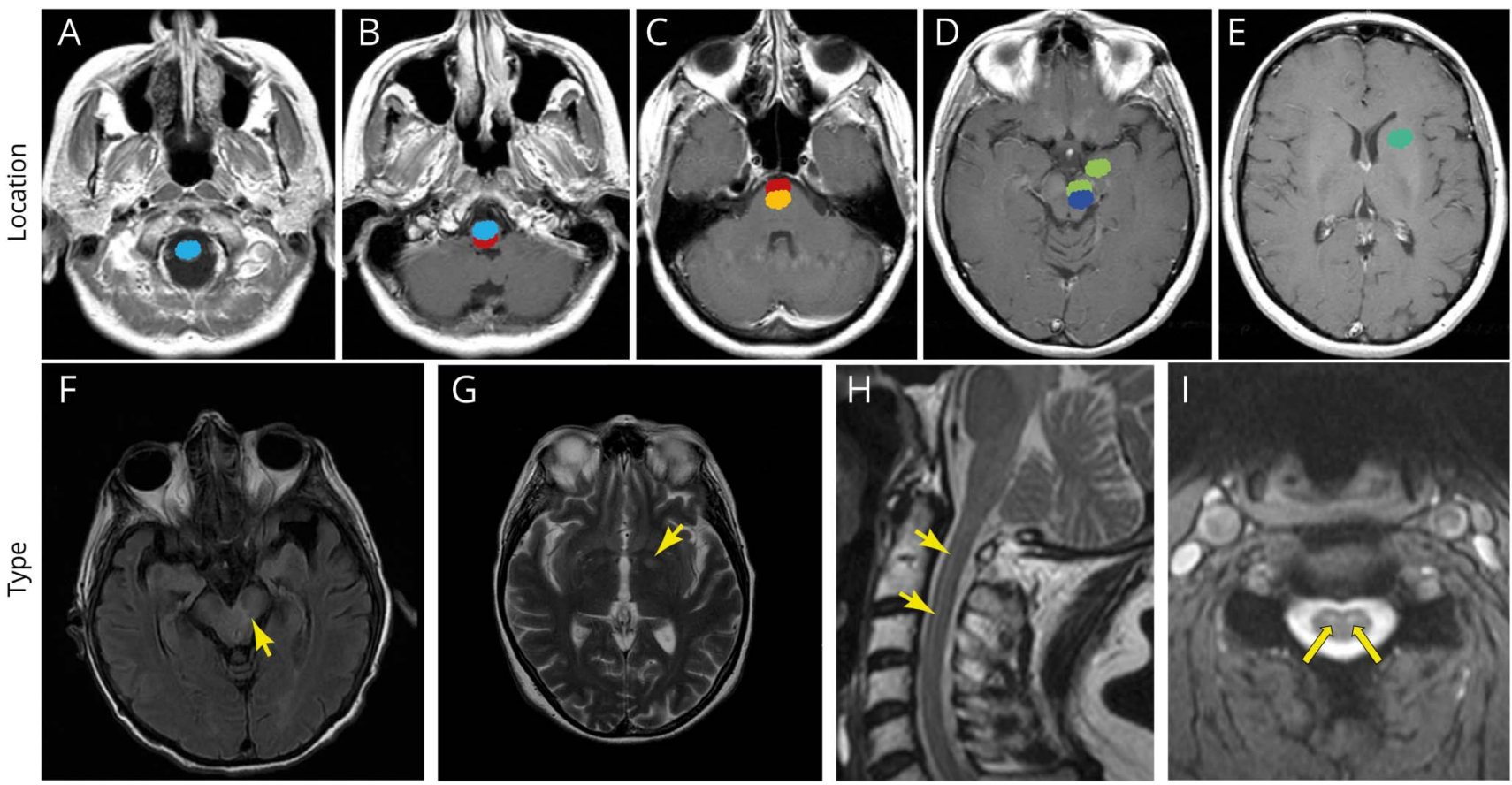

Location (A-E) and type (F-I) of the different neuroradiologic alterations (mainly T2-weighted and fluid-attenuated inversion recovery [FLAIR] hyperintensities) detected in the French cohort of patients with Ri-PNS; each color represents a different patient (MRI abnormalities [arrows]). Note the prominent involvement of the upper cervical cord (A), brainstem structures (B-D), mesial temporal lobe (D), and basal ganglia (E). Ri-PNS = Ri-associated paraneoplastic neurologic syndrome.

analysis. There was no significant difference in terms of clinical or demographic characteristics, other than a significantly greater number of paraneoplastic cases among the French cohort $(p=0.023$; table 1$)$.

\section{Discussion}

This study provides several important findings concerning the clinical spectrum of patients with Ri-PNS. Most patients with Ri-PNS have a multisystem neurologic involvement, although the cerebellum and the brainstem are most commonly affected. Opsoclonus with or without myoclonus constitutes only a part of the clinical spectrum of this disease, as it appears to be less frequent than previously expected and rarely appears as an isolated manifestation. The typical progression is that of a cerebellar syndrome presenting with subacute gait ataxia, followed in a second stage by signs/ symptoms of brainstem involvement, and subsequent involvement of the pyramidal system and basal ganglia. Symptom development is often slower than those of other PNS, showing a chronic course in a large proportion of patients, thus mimicking neurodegenerative conditions. The disorder predominates in females, and breast cancer is the most common cancer type overall.

The original descriptions of Ri-PNS defined OMS as the stereotyped manifestation of this disease. ${ }^{1-8,13-16}$ However, we demonstrate herein that the clinical phenotype is more heterogeneous and usually involves multiple neurologic systems, the core manifestation being a cerebellar syndrome. It is of note that OMS was present in only a quarter of the French cohort cases, and none of them presented with OMS as an isolated manifestation; the absence of OMS should therefore not exclude the diagnosis of a Ri-PNS.

According to the data presented herein, Ri-PNS is a rare disease, but we suspect that it is largely underdiagnosed. The stepwise course of the syndrome, usually subacute but chronic/progressive in almost $30 \%$ of patients, can lead to diagnostic delays or to misdiagnose the disorder as a primarily neurodegenerative disease or as a nonparaneoplastic inflammatory brain disease, thus preventing the early discovery of cancer. This is further supported by the frequency of misdiagnosis that was high in the French cohort. By reviewing critically all available cases, we were able to define a list of differential diagnoses in which Ri-PNS should be considered. The latter are characterized by a subacute/ progressive ataxia-plus syndrome that develops in patients without structural or vascular brain abnormalities (table 2). In particular, in cases in which ophthalmoplegia associates with ataxia and abnormal reflexes on examination (11\% of patients in the French Cohort), the presentation is strongly suggestive of Bickerstaff brainstem encephalitis (BBE), a postinfectious inflammatory brain disease. Both brain MRI and CSF tests are not able to distinguish between the 2 conditions; only a positive test for serum anti-GQ1b antibody, positive in $66 \%$ of patients with $\mathrm{BBE}$, would allow 
Table 1 Comparison of Ri-PNS clinical features between patients reported in the literature and those from the French cohort

\begin{tabular}{|c|c|c|c|}
\hline & $\begin{array}{l}\text { French cohort } \\
(n=33)^{a}\end{array}$ & $\begin{array}{l}\text { Literature } \\
(n=55)^{a}\end{array}$ & $p$ Value \\
\hline Sex, male, n (\%) & $7(21.2)$ & $12(22.2)^{b}$ & 0.912 \\
\hline \multicolumn{4}{|l|}{ Clinical features, n (\%) } \\
\hline Cerebellar syndrome & $22(66.7)$ & $37(67.3)$ & 1 \\
\hline Oculomotor & 19 (57.6) & 20 (36.4) & 0.076 \\
\hline Myoclonus & 10 (30.3) & $23(41.8)$ & 0.364 \\
\hline Spasticity & 10 (30.3) & 18 (32.7) & 1 \\
\hline Dystonia & $11(33.3)$ & $8(14.5)$ & 0.06 \\
\hline $\begin{array}{l}\text { Peripheral } \\
\text { neuropathy }\end{array}$ & $6(18.2)$ & $8(14.5)$ & 0.765 \\
\hline Cancer & 31 (93.9) & $40(72.7)$ & $0.023^{d}$ \\
\hline \multicolumn{4}{|l|}{ Cancer type, n (\%) } \\
\hline Breast & 21 (67.7) & 19 (47.5) & 0.099 \\
\hline Lung & $2(6.5)$ & $10(25)$ & 0.055 \\
\hline Otherc & $8(25.8)$ & $11(27.5)$ & 1 \\
\hline
\end{tabular}

Abbreviation: Ri-PNS = Ri-associated paraneoplastic neurologic syndrome. a Patients with Ri-PNS without coexisting antibodies.

b The sex of the patient is lacking in 1 case from the literature.

c Other cancer included bladder cancer, mediastinal seminoma, and cancer without available histology.

${ }^{\mathrm{d}} p$ Value is statistically significant.

a correct diagnosis. ${ }^{17}$ For example, it has been reported that a patient who presented initially with ophthalmoparesis, tetraparesis, and areflexia following a Campylobacter jejuni-related gastroenteritis, received an initial diagnosis of BBE-Guillain-Barré overlap syndrome, later proven to be an Ri-PNS associated with breast cancer. ${ }^{18}$ Aside from BBE, another relevant differential diagnosis for the Ri-PNS is represented by the group of atypical parkinsonisms, particularly progressive supranuclear palsy (PSP). Both PSP and Ri-PNS can present with supranuclear gaze palsy or ophthalmoplegia and repeated unprovoked falls, in the context of tremor, rigidity, and bradykinesia (14\% of the cases in the French cohort). This presentation would likely lead to a diagnosis of probable PSP, although a sudden onset or stepwise or rapid progression should alert the clinician to look for other diagnoses, including autoimmune conditions. ${ }^{19}$ We believe that patients with Ri-PNS and chronic/progressive course could be missed if this set of criteria is applied strictly.

Despite previous emphasis of Ri-PNS association with lung cancer, ${ }^{10}$ we demonstrate herein that, overall, breast cancer is the most frequent tumor found in patients with Ri-PNS. The analysis of the literature series further confirmed this finding. The important implication is that women with $\mathrm{Ri}$ antibodies, who account for 3 quarters of patients, should be investigated for the presence of breast cancer, and diagnostic surveillance should continue in cases in which cancer is not detected at the onset of the neurologic syndrome. Conversely, male patients usually harbor neuroendocrine tumors (lung or bladder) or mediastinal seminoma. A rational approach would therefore be to begin the search for an occult cancer with clinical examination and first-level tests (mammography and breast ultrasound) in women, and whole-body CT scan in men, when $\mathrm{Ri}$ antibodies are found. Of interest, none of the breast cancers analyzed herein demonstrated HER2 overexpression, which is usually found in approximately $20 \%$ of patients with breast cancer in general. $^{20}$ Conversely, $96 \%$ of the tumors in anti-Yoassociated PNS demonstrate HER2 overexpression, strongly suggesting a different pathogenesis for the 2 diseases. $^{20}$

Isolated confusion, SIADH-related hyponatremia, and severe dysautonomia were not previously reported as possible manifestations of $\mathrm{Ri}$ autoimmunity. This allows us to expand the clinical spectrum of the disease. We acknowledge that hyponatremia, especially if severe, could worsen the neurologic status of patients and contribute to the disturbances of gait and confusion. ${ }^{21}$ Severe dysautonomia resulted in life-threatening arrhythmias, and 1 of the patients experienced repeated episodes of cardiac arrests while he was in the intensive care unit (ICU). Dysautonomia was associated with Ondine syndrome, or central hypoventilation, characterized by normal ventilation while the patient is awake, but severe hypoventilation when asleep. Acquired central hypoventilation can result from pathologic involvement of the brainstem respiratory nuclei, as it was observed in other autoimmune conditions, including anti-Hu brainstem syndrome and anti-N-methylD-aspartate receptor encephalitis. ${ }^{22,23}$ Therefore, initial management and monitoring of patients in the ICU should be systematically proposed if brainstem involvement is present. Despite its phenotypical heterogeneity, there is a specific biological reason for the predilection of the autoimmune process to damage specific anatomic targets, which correspond to the different expression of the $\mathrm{Ri}$ antigens also called neurooncologic ventral antigen (NOVA)-1 and NOVA-2 in the brain. ${ }^{24}$ The neuroradiologic abnormalities detected were also in agreement with this distribution, characterized mainly by subtle alterations confined to the brainstem region. The presence of contrast enhancement at the mesial temporal lobe level in one of our patients is an interesting finding, which was previously reported in $\mathrm{Ma} 2$ antibody-associated syndrome. ${ }^{25-28}$

The present study highlights the grim prognosis of patients with Ri-PNS: at 1 year, most of the French patients were unable to walk unassisted, and half of them died within 3 years of disease onset. These findings are in contrast with the favorable prognosis and good functional outcome suggested by others. ${ }^{29}$ However, we did observe a case with spectacular improvement following breast cancer treatment. Therefore, 
Table 2 Differential diagnosis spectrum of late-onset, sporadic, progressive cerebellar-plus syndrome in patients without structural or vascular brain lesions, in which anti-Ri-PNS should be considered

\begin{tabular}{|c|c|c|c|c|c|c|}
\hline Diagnosis & $\begin{array}{l}\text { Cerebellar } \\
\text { syndrome }\end{array}$ & Parkinsonism & Dystonia & $\begin{array}{l}\text { Oculomotor } \\
\text { disturbances }\end{array}$ & Myoclonus & Red flags \\
\hline $\begin{array}{l}\text { Progressive supranuclear } \\
\text { palsy (PSP) }\end{array}$ & $++($ PSP-C) & +++ & $\begin{array}{l}+ \text { (Nuchal } \\
\text { dystonia with } \\
\text { retrocollis) }\end{array}$ & +++ & $+(\mathrm{PSP}-\mathrm{CBS})$ & $\begin{array}{l}\text { Gradual progression, vertical } \\
\text { supranuclear gaze palsy, frequent } \\
\text { falls, and freezing of gait }\end{array}$ \\
\hline $\begin{array}{l}\text { Multiple system atrophy } \\
\text { (MSA) }\end{array}$ & $\begin{array}{l}+++ \\
(\mathrm{MSA}-\mathrm{C})\end{array}$ & +++ & $\begin{array}{l}+ \text { (Orofacial } \\
\text { dystonia) }\end{array}$ & + & + & $\begin{array}{l}\text { Autonomic failure (urinary } \\
\text { incontinence, erectile dysfunction, } \\
\text { and orthostatic hypotension) }\end{array}$ \\
\hline $\begin{array}{l}\text { Creutzfeldt-Jakob } \\
\text { disease (CJD) }\end{array}$ & $\begin{array}{l}++ \\
\text { (Cerebellar } \\
\text { variant) }\end{array}$ & ++ & + & + & +++ & Rapidly progressive dementia \\
\hline $\begin{array}{l}\text { Niemann-Pick disease } \\
\text { type-C (NPC, late onset) }\end{array}$ & +++ & + & + & $\begin{array}{l}\text { +++ (Impaired } \\
\text { saccadic eye } \\
\text { movement) }\end{array}$ & + & $\begin{array}{l}\text { Psychiatric features, gelastic } \\
\text { cataplexy, hepato-spenomegaly }\end{array}$ \\
\hline $\begin{array}{l}\text { Progressive } \\
\text { encephalopathy with } \\
\text { rigidity and myoclonus } \\
\text { (PERM) }\end{array}$ & ++ & - & - & ++ & +++ & - \\
\hline Anti-DPPX syndrome & ++ & + & Uncommon & +++ & +++ & $\begin{array}{l}\text { Gastrointestinal dysmotility, } \\
\text { diarrhea, } \\
\text { and cognitive disorders }\end{array}$ \\
\hline $\begin{array}{l}\text { Bickerstaff brainstem } \\
\text { encephalitis }\end{array}$ & +++ & - & - & +++ & - & $\begin{array}{l}\text { Antecedent infective illness in most } \\
\text { patients; serum anti-GQ1b in } 66 \% \\
\text { of cases; disturbance of } \\
\text { consciousness } \\
\text { and facial diplegia are common }\end{array}$ \\
\hline Anti-IgLON5 syndrome & +++ & + & + & ++ & + & $\begin{array}{l}\text { Sleep problems including } \\
\text { sleep-disordered breathing } \\
\text { and parasomnias are common }\end{array}$ \\
\hline
\end{tabular}

despite the overall unsatisfactory effect of therapy, we believe that early cancer treatment and response evaluation to immunotherapy are reasonable options in these patients, as in other PNS. $^{30}$

The present study is limited by its retrospective nature. Nevertheless, it represents the 20-year experience of a reference center, and the analysis of all cases described in the literature allowed us to redefine the main features of this disease.

In conclusion, Ri-PNS is characterized by prominent cerebellar and brainstem involvement, followed by multisystem neurologic dysfunction, with a subacute or chronic/ progressive course. This could mislead diagnosis toward a neurodegenerative or an inflammatory nonparaneoplastic condition, during which the presence of underlying tumor would not be investigated. Most patients are women with an associated breast tumor, whereas male patients have a wider cancer association. During the course of the disease, several movement disorders could complicate the picture further, including parkinsonism, cervical and oromandibular dystonia, and SPS. Opsoclonus with or without myoclonus is only a part of the clinical spectrum and is rarely observed as an isolated finding. Neurologists should thus be aware of the more complex phenotype associated with Ri antibodies.

\section{Acknowledgment}

The authors thank NeuroBioTec Hospices Civils de Lyon BRC (France, AC-2013-1867, NFS96-900) for banking sera and CSF samples. They gratefully acknowledge Philip Robinson and Verena Landel for English language editing (Direction de la Recherche Clinique, Hospices Civils de Lyon).

\section{Study funding}

This study is supported by research grants from ANR (ANR-14-CE15-0001-MECANO) and FRM (Fondation pour la Recherche Medicale) DQ20170336751. This work has been developed within the BETPSY project, which is supported by a public grant overseen by the French National Research Agency (ANR), as part of the second "Investissements d'Avenir" program (reference ANR-18RHUS-0012).

\section{Disclosure}

The authors have no conflicts of interest to disclose. Go to Neurology.org/NN for full disclosures.

\section{Publication history}

Received by Neurology: Neuroimmunology \& Neuroinflammation December 23, 2019. Accepted in final form February 3, 2020. 
Appendix Authors

\begin{tabular}{lll}
\hline Name & Location & Contribution \\
\hline $\begin{array}{l}\text { Claire Simard, } \\
\text { MD }\end{array}$ & $\begin{array}{l}\text { Hospices Civils de } \\
\text { Lyon, France }\end{array}$ & $\begin{array}{l}\text { Designed and conceptualized } \\
\text { the study; major role in the } \\
\text { acquisition of data; and } \\
\text { analyzed the data }\end{array}$ \\
\hline
\end{tabular}

\begin{tabular}{lll}
\hline $\begin{array}{l}\text { Alberto } \\
\text { Vogrig, MD }\end{array}$ & $\begin{array}{l}\text { Hospices Civils de } \\
\text { Lyon, France }\end{array}$ & $\begin{array}{l}\text { Designed and conceptualized } \\
\text { the study; analyzed the data; } \\
\text { and drafted the manuscript for } \\
\text { intellectual content }\end{array}$ \\
\hline
\end{tabular}

\begin{tabular}{lll}
\hline $\begin{array}{l}\text { Bastien } \\
\text { Joubert, MD }\end{array}$ & $\begin{array}{l}\text { Hospices Civils de } \\
\text { Lyon, France }\end{array}$ & $\begin{array}{l}\text { Interpreted the data and } \\
\text { revised the manuscript for } \\
\text { intellectual content }\end{array}$ \\
\hline $\begin{array}{l}\text { Sergio Muñiz- } \\
\text { Castrillo, MD }\end{array}$ & $\begin{array}{l}\text { Hospices Civils de } \\
\text { Lyon, France }\end{array}$ & $\begin{array}{l}\text { Interpreted the data and } \\
\text { revised the manuscript for } \\
\text { intellectual content }\end{array}$ \\
\hline $\begin{array}{l}\text { Géraldine } \\
\text { Picard }\end{array}$ & $\begin{array}{l}\text { Hospices Civils de } \\
\text { Lyon, France }\end{array}$ & $\begin{array}{l}\text { Acquisition of data and revised } \\
\text { the manuscript for intellectual } \\
\text { content }\end{array}$ \\
\hline
\end{tabular}

\begin{tabular}{|c|c|c|}
\hline $\begin{array}{l}\text { Véronique } \\
\text { Rogemond, } \\
\text { PhD }\end{array}$ & $\begin{array}{l}\text { Hospices Civils de } \\
\text { Lyon, France }\end{array}$ & $\begin{array}{l}\text { Acquisition of data and revised } \\
\text { the manuscript for intellectual } \\
\text { content }\end{array}$ \\
\hline $\begin{array}{l}\text { François } \\
\text { Ducray, MD, } \\
\text { PhD }\end{array}$ & $\begin{array}{l}\text { Hospices Civils de } \\
\text { Lyon, France }\end{array}$ & $\begin{array}{l}\text { Interpreted the data and } \\
\text { revised the manuscript for } \\
\text { intellectual content }\end{array}$ \\
\hline $\begin{array}{l}\text { Giulia } \\
\text { Berzero, MD }\end{array}$ & $\begin{array}{l}\text { Groupe Hospitalier } \\
\text { Pitié-Salpêtrière, } \\
\text { Paris, France }\end{array}$ & $\begin{array}{l}\text { Interpreted the data and } \\
\text { revised the manuscript for } \\
\text { intellectual content }\end{array}$ \\
\hline $\begin{array}{l}\text { Dimitri } \\
\text { Psimaras, MD }\end{array}$ & $\begin{array}{l}\text { Groupe Hospitalier } \\
\text { Pitié-Salpêtrière, } \\
\text { Paris, France }\end{array}$ & $\begin{array}{l}\text { Interpreted the data and } \\
\text { revised the manuscript for } \\
\text { intellectual content }\end{array}$ \\
\hline $\begin{array}{l}\text { Jean- } \\
\text { Christophe } \\
\text { Antoine, MD, } \\
\text { PhD }\end{array}$ & $\begin{array}{l}\text { CHU de Saint- } \\
\text { Etienne, Saint- } \\
\text { Etienne, France }\end{array}$ & $\begin{array}{l}\text { Interpreted the data and } \\
\text { revised the manuscript for } \\
\text { intellectual content }\end{array}$ \\
\hline $\begin{array}{l}\text { Virginie } \\
\text { Desestret, } \\
\text { MD, PhD }\end{array}$ & $\begin{array}{l}\text { Hospices Civils de } \\
\text { Lyon, France }\end{array}$ & $\begin{array}{l}\text { Interpreted the data and } \\
\text { revised the manuscript for } \\
\text { intellectual content }\end{array}$ \\
\hline $\begin{array}{l}\text { Jérôme } \\
\text { Honnorat, } \\
\text { MD, PhD }\end{array}$ & $\begin{array}{l}\text { Hospices Civils de } \\
\text { Lyon, France }\end{array}$ & $\begin{array}{l}\text { Designed and conceptualized } \\
\text { the study; interpreted the data; } \\
\text { revised the manuscript for } \\
\text { intellectual content; and study } \\
\text { supervision }\end{array}$ \\
\hline
\end{tabular}

\section{References}

1. Budde-Steffen C, Anderson NE, Rosenblum MK, et al. An antineuronal autoantibody in paraneoplastic opsoclonus. Ann Neurol 1988;23:528-531.

2. Luque FA, Furneaux HM, Ferziger R, et al. Anti-Ri: an antibody associated with paraneoplastic opsoclonus and breast cancer. Ann Neurol 1991;29:241-251.

3. Dropcho EJ, Kline LB, Riser J. Antineuronal (anti-Ri) antibodies in a patient with steroid-responsive opsoclonus-myoclonus. Neurology 1993;43:207-211.

4. Bataller L, Graus F, Saiz A, Vilchez JJ; Spanish Opsoclonus-Myoclonus Study Group. Clinical outcome in adult onset idiopathic or paraneoplastic opsoclonus-myoclonus. Brain 2001;124:437-443.

5. Prestigiacomo CJ, Balmaceda C, Dalmau J. Anti-Ri-associated paraneoplastic opsoclonus-ataxia syndrome in a man with transitional cell carcinoma. Cancer 2001; 91:1423-1428.
6. Wirtz PW, Sillevis Smitt PAE, Hoff JI, et al. Anti-Ri antibody positive opsoclonusmyoclonus in a male patient with breast carcinoma. J Neurol 2002;249:1710-1712.

7. Weizman DA, Leong WL. Anti-Ri antibody opsoclonus-myoclonus syndrome and breast cancer: a case report and a review of the literature. J Surg Oncol 2004;87: 143-145.

8. Armangué T, Sabater L, Torres-Vega E, et al. Clinical and immunological features of opsoclonus-myoclonus syndrome in the era of neuronal cell surface antibodies. JAMA Neurol 2016;73:417-424.

9. Romorini A, Frediani F, Rapuzzi S, Patruno G, Lamperti E, Nemni R. Anti-Ri antibodies and peripheral neuropathy in a man without malignancy. Eur Neurol 2004;51: 177-178.

10. Pittock SJ, Lucchinetti CF, Lennon VA. Anti-neuronal nuclear autoantibody type 2: paraneoplastic accompaniments. Ann Neurol 2003;53:580-587.

11. Waters P, Pettingill P, Lang B. Detection methods for neural autoantibodies. Handb Clin Neurol 2016;133:147-163.

12. Moher D, Liberati A, Tetzlaff J, Altman DG, Group TP. Preferred reporting items for systematic reviews and meta-analyses: the PRISMA statement. PLoS Med 2009;6: e1000097.

13. Escudero D, Barnadas A, Codina M, Fueyo J, Graus F. Anti-Ri-associated paraneoplastic neurologic disorder without opsoclonus in a patient with breast cancer. Neurology 1993;43:1605-1606.

14. Casado JL, Gil-Peralta A, Graus F, Arenas C, Lopez JM, Alberca R. Anti-Ri antibodies associated with opsoclonus and progressive encephalomyelitis with rigidity. Neurology 1994;44:1521-1522.

15. Jongen JL, Moll WJ, Sillevis Smitt PA, Vecht CJ, Tijssen CC. Anti-Ri positive opsoclonus-myoclonus-ataxia in ovarian duct cancer. J Neurol 1998;245:691-692.

16. Thümen A, Moser A. An uncommon paraneoplastic Ri-positive opsoclonusmyoclonus-like syndrome and Stiff-Person syndrome with elevated glutamate/ GABA ratio in the cerebrospinal fluid after breast cancer. J Neurol 2010;257: 1215-1217.

17. Odaka M, Yuki N, Yamada M, et al. Bickerstaff's brainstem encephalitis: clinical features of 62 cases and a subgroup associated with Guillain-Barré syndrome. Brain 2003;126:2279-2290.

18. Rajabally YA, Naz S, Farrell D, Abbott RJ. Paraneoplastic brainstem encephalitis with tetraparesis in a patient with anti-Ri antibodies. J Neurol 2004;251:1528-1529.

19. Hoglinger GU, Respondek G, Stamelou M, et al. Clinical diagnosis of progressive supranuclear palsy: the movement disorder society criteria. Mov Disord 2017;32: 853-864.

20. Rojas-Marcos I, Picard G, Chinchón D, et al. Human epidermal growth factor receptor 2 overexpression in breast cancer of patients with anti-Yo-associated paraneoplastic cerebellar degeneration. Neuro Oncol 2012;14:506-510.

21. Pelosof LC, Gerber DE. Paraneoplastic syndromes: an approach to diagnosis and treatment. Mayo Clin Proc 2010;85:838-854.

22. Uchino A, Iizuka T, Urano Y, et al. Pseudo-piano playing motions and nocturnal hypoventilation in anti-NMDA receptor encephalitis: response to prompt tumor removal and immunotherapy. Intern Med 2011;50:627-630.

23. Najjar M, Taylor A, Agrawal S, et al. Anti-Hu paraneoplastic brainstem encephalitis caused by a pancreatic neuroendocrine tumor presenting with central hypoventilation. J Clin Neurosci 2017;40:72-73.

24. Buckanovich RJ, Posner JB, Darnell RB. Nova, the paraneoplastic Ri antigen, is homologous to an RNA-binding protein and is specifically expressed in the developing motor system. Neuron 1993;11:657-672.

25. Vogrig A, Fouret M, Joubert B, et al. Increased frequency of anti-Ma2 encephalitis associated with immune checkpoint inhibitors. Neurol Neuroimmunol Neuroinflamm 2019;6:e604. doi: 10.1212/NXI.0000000000000604.

26. Dalmau J. Clinical analysis of anti-Ma2-associated encephalitis. Brain 2004;127: 1831-1844.

27. Vogrig A, Ferrari S, Tinazzi M, Manganotti P, Vattemi G, Monaco S. Anti-Maassociated encephalomyeloradiculopathy in a patient with pleural mesothelioma. J Neurol Sci 2015;350:105-106.

28. Vogrig A, Joubert B, Maureille A, et al. Motor neuron involvement in anti-Ma2associated paraneoplastic neurological syndrome. J Neurol 2019;266:398-410.

29. Shams'ili S, Grefkens J, de Leeuw B, et al. Paraneoplastic cerebellar degeneration associated with antineuronal antibodies: analysis of 50 patients. Brain 2003;126: 1409-1418.

30. Vogrig A, Pauletto G, Belgrado E, et al. Effect of thymectomy on refractory autoimmune status epilepticus. J Neuroimmunol 2018;317:90-94.

31. Krzywinski M, Schein J, Birol İ, et al. Circos: an information aesthetic for comparative genomics. Genome Res 2009;19:1639-1645. 


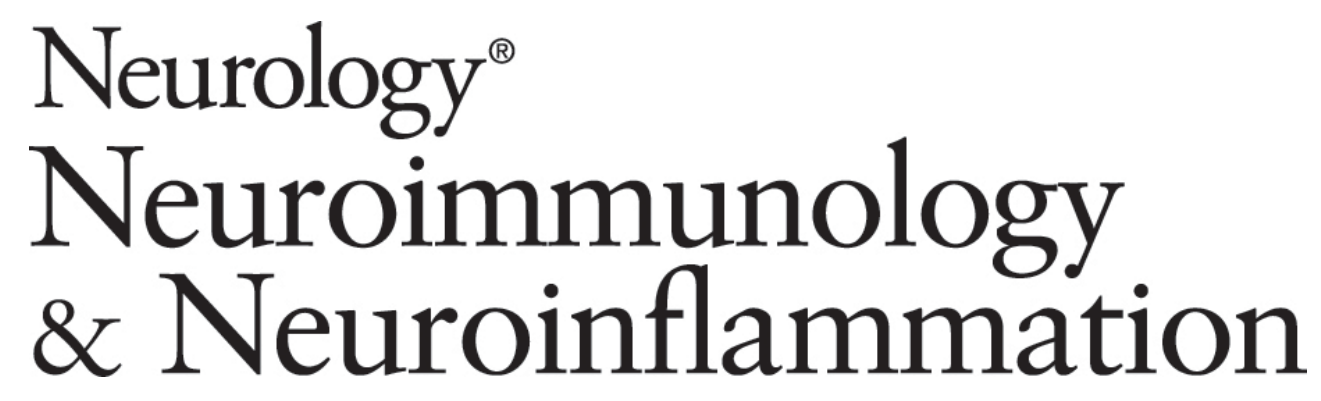

Clinical spectrum and diagnostic pitfalls of neurologic syndromes with Ri antibodies Claire Simard, Alberto Vogrig, Bastien Joubert, et al.

Neurol Neuroimmunol Neuroinflamm 2020;7;

DOI 10.1212/NXI.0000000000000699

This information is current as of March 13, 2020

Neurol Neuroimmunol Neuroinflamm is an official journal of the American Academy of Neurology.

Published since April 2014, it is an open-access, online-only, continuous publication journal. Copyright

Copyright $\odot 2020$ The Author(s). Published by Wolters Kluwer Health, Inc. on behalf of the American

Academy of Neurology.. All rights reserved. Online ISSN: 2332-7812.

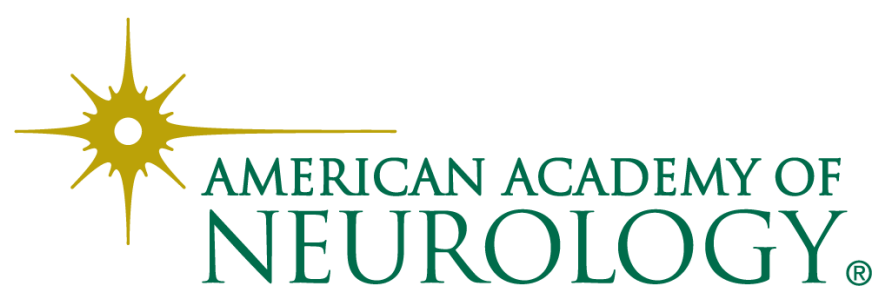




\section{Updated Information \& Services}

References

Citations

Subspecialty Collections

Permissions \& Licensing

Reprints including high resolution figures, can be found at: http://nn.neurology.org/content/7/3/e699.full.html

This article cites 31 articles, 2 of which you can access for free at: http://nn.neurology.org/content/7/3/e699.full.html\#\#ref-list-1

This article has been cited by 2 HighWire-hosted articles: http://nn.neurology.org/content/7/3/e699.full.html\#\#otherarticles

This article, along with others on similar topics, appears in the following collection(s):

\section{All Movement Disorders}

http://nn.neurology.org//cgi/collection/all_movement_disorders Autoimmune diseases

http://nn.neurology.org//cgi/collection/autoimmune_diseases

Gait disorders/ataxia

http://nn.neurology.org//cgi/collection/gait_disorders_ataxia

Paraneoplastic syndrome

http://nn.neurology.org//cgi/collection/paraneoplastic_syndrome Parkinson's disease/Parkinsonism

http://nn.neurology.org//cgi/collection/parkinsons_disease_parkinsonis $\mathrm{m}$

Information about reproducing this article in parts (figures,tables) or in its entirety can be found online at:

http://nn.neurology.org/misc/about.xhtml\#permissions

Information about ordering reprints can be found online:

http://nn.neurology.org/misc/addir.xhtml\#reprintsus

Neurol Neuroimmunol Neuroinflamm is an official journal of the American Academy of Neurology.

Published since April 2014, it is an open-access, online-only, continuous publication journal. Copyright

Copyright $\odot 2020$ The Author(s). Published by Wolters Kluwer Health, Inc. on behalf of the American

Academy of Neurology.. All rights reserved. Online ISSN: 2332-7812.

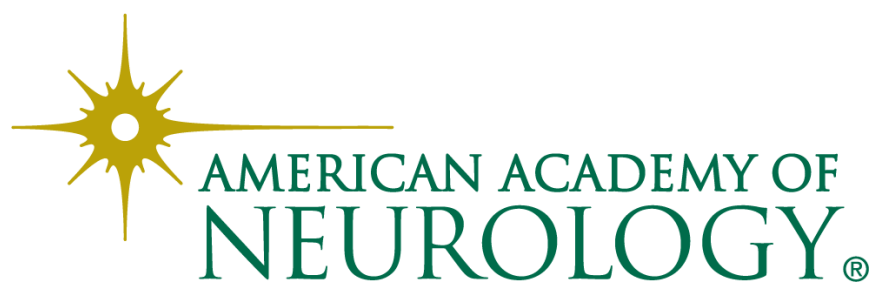

